\title{
A FELÜLETI ÉRDESSÉG KIALAKULÁSÁNAK ELEMZÉSE ESZTERGÁLÁSI ÉS MARÁSI MÛVELETEKNÉL
}

\section{ANALYSIS OF FORMATION OF SURFACE ROUGHNESS IN CASE OF TURNING AND MILLING PROCESSES}

\author{
Palásti-Kovács Béla ${ }^{1}$, Ács Dániel ${ }^{2}$, Ráczi Viktor ${ }^{3}$ \\ I'Óbudai Egyetem, Bánki Donát Gépész és Biztonságtechnikai Mérnöki Kar, H-1081 \\ Budapest, Népszínház u. 8. Telefon: +36-1-666-5356,palasti@uni-obuda.hu \\ ${ }^{2}$ Óbudai Egyetem, Bánki Donát Gépész és Biztonságtechnikai Mérnöki Kar, H-1081 \\ Budapest, Népszínház u. 8. Telefon: +36-1-666-5391, danielacs2091@gmail.com \\ ${ }^{3}$ Óbudai Egyetem, Bánki Donát Gépész és Biztonságtechnikai Mérnöki Kar, H-1081 \\ Budapest, Népszínház u. 8. Telefon: +36-1-666-5356,raczi.viktor@gmail.com
}

\begin{abstract}
Surface roughness and the quality of surfaces of machine elements play important role in safety and reliable operation of technical devices. Present study shows that different machining processes results dissimilar microgeometry with variety of surface parameters. Formation mechanisms of surface roughness are analysed based on turning and milling tests. It is indicated that significant changes occur in amplitude, average and shape of cut surface during wear and cutting edge degradation processes of tools. In case of milling, behind the cutting parameters and geometric data the run-out has significant effect for the roughness of milled surface.
\end{abstract}

Keywords: surface roughness, tool wear, tool accuracy, tool run-out.

\section{Összefoglalás}

Müszaki eszközeink megbízhatóságának és biztonságos müködésének kulcsfontosságú része az alkatrészek felülete, a kapcsolódó gépelemek felületminősége, érdessége. Jelen munkában bemutatjuk, hogy az egyes forgácsolási eljárások különböző mikrogeometriát és eltérő érdességi értékeket hoznak létre. Kísérleti példákon elemezzük az érdesség kialakulásának mechanizmusát esztergálási és marási müveleteknél. Rámutatunk arra, hogy a gyártás során a szerszámok elhasználódása alatt bekövetkező kopás és vágóél-változás a megmunkált felületen jelentős magassági- átlagos- és formai eltéréseket okoz. Marásnál rámutatunk arra, hogy a forgácsolási és geometriai adatok mellett a szerszám, valamint a megmunkáló rendszer ütésének döntően meghatározó szerepe van a mart felület érdességére.

Kulcsszavak: felületi érdesség, szerszámkopás, szerszám pontosság, szerszámütés.

\section{Bevezetés}

Gyártás, minőség, működés - egymástól elválaszthatatlan fogalmak. Minden olyan elöírás és probléma, amely a kapcsolódó alkatrészek gyártásánál felmerül, jelentős hatással lehet a müködésre.
Az Óbudai Egyetem Bánki Karán közel négy évtizede foglalkozunk a felületi mikrogeometria vizsgálatával, a megmunkáláskor kapott felületprofilok, topográfiák kiértékelésével, a forgácsolt felület és a felületet kialakító szerszámél közvetlen kapcsolatával, egymásra hatásával [1]. 
Számos forgácsolási eljárást (esztergálás, fúrás, marás, köszörülés, szuperfiniselés, stb.) vizsgáltunk meg abból a célból, hogy feltárjuk az egyes megmunkálások mikrogeometriai jellegzetességeit (1. ábra), az érdesség kialakulásának mechanizmusát [2].
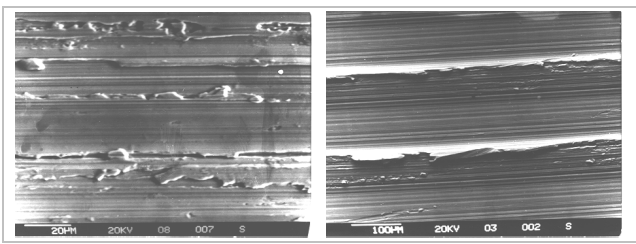

1. ábra. Köszörült, ill. finomesztergált felület elektronmikroszkópos képe

Vizsgálatainkból összegezhető, hogy egy adott megmunkálással előállított felület sem méréstechnikai, sem gyártási szempontból nem tekinthető homogénnek. Ugyanazon felületet jellemző, egymáshoz közeleső mérésekből kapott érdességi paraméterek jelentős eltérést mutathatnak, akár elérhetik a 70-100\%-ot is [1].

A 2. ábra közel azonos Ra értékü mart, köszörült és szuperfiniselt felület mikrogeometriai profilját mutatja. Jól elkülöníthetők az alaki jellegzetességek, ami azt is elörevetíti, hogy müködés közben is másként viselkednek.

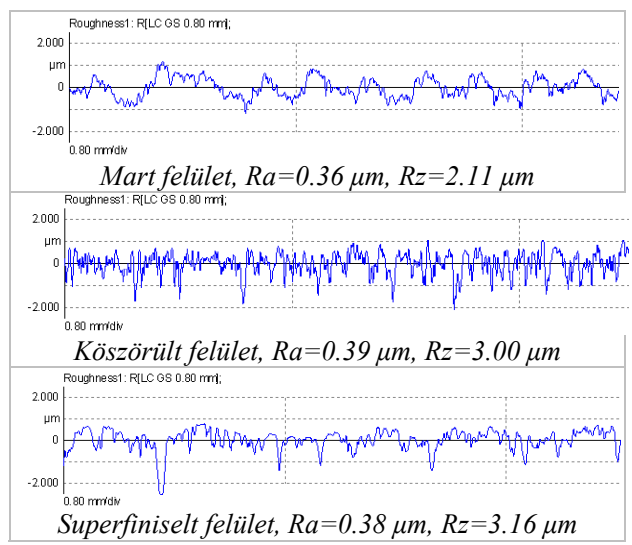

2. ábra. Forgácsolt felület - érdességi profilok $(R a=0,36 \ldots 0,43 \mu m, R z / R a=5,8 \ldots 9,5)$

\section{Az esztergált felület kialakulása a forgácsolási folyamatban}

Egy esztergált felületet megfelelő nagyításban vizsgálva jól megfigyelhetök a megmunkálás geometriai nyomai (3. ábra). Ezek ismétlődő csúcsok, barázdák, kiemelkedések (felrakódások) és mélyedések (kitépődések).

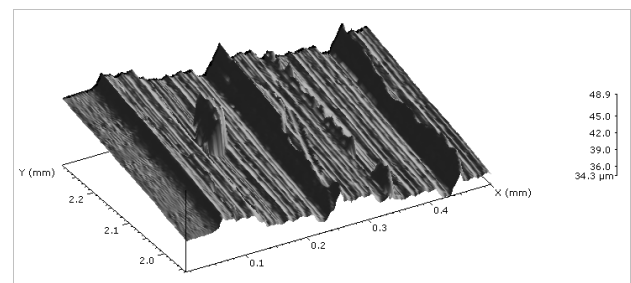

3. ábra. Esztergált felület mikrogeometriai jellegzetességei

A megmunkálási folyamat kinematikája, a szerszám geometriai jellemzői és a megmunkálandó anyag fizikai-mechanikai tulajdonságai határozzák meg a felületen kialakuló mikrogeometriai alakzatot. E tényezők változása a megmunkálási folyamatban lényeges különbségeket okozhatnak a felület mikrogeometriájában [2]. Sorozatgyártás esetén mindez komoly kihívást jelent a felületérdességi mérőszámok előírt értékének folyamatos betartásában.

A főbb tényezők hatását elméleti összefüggések írják le, ilyenek a Bauer-képlet és a Brammertz-formula:

$$
\begin{array}{ll}
R z \approx R_{e}=125 \cdot \frac{f^{2}}{r_{\varepsilon}}[\mu m], & \text { illetőleg } \\
R z \approx R_{e B r}=125 \cdot \frac{f^{2}}{r_{\varepsilon}}+h_{\min } \cdot\left(0.5+\frac{r_{\varepsilon} \cdot h_{\min }}{2000 \cdot f^{2}}\right) & {[\mu \mathrm{m}] .}
\end{array}
$$

ahol: $\mathrm{f}-$ beállított előtolás, $\mathrm{mm}, \mathrm{r}_{\varepsilon}-\mathrm{a}$ szerszám csúcssugara, $\mathrm{mm}, \mathrm{h}_{\min }-\mathrm{a}$ leválasztható minimális forgácsvastagság, azaz $\mathrm{h}_{\min }=\mathrm{f}\left(\mathrm{v}_{\mathrm{c}}, \mathrm{r}_{\mathrm{n}}, \mathrm{stb}.\right)=3 \ldots 8 \mu \mathrm{m}, \mathrm{r}_{\mathrm{n}}-\mathrm{a}$ szerszámél éllekerekedése.

A további befolyásoló tényezők között az időbeli változásnak igen jelentős szerepe lehet. Simító esztergálásra közölt kutatá- 
sokból [3] az szürhető le, hogy 15-20 perc forgácsolási idő alatt az Ra érték kb. $1 \mu \mathrm{m}$ rel való növekedését eredményezi. Ez csak a változás trendjét és nagyságát prognosztizálja, kevéssé mutat rá a szerszámkopás hatására bekövetkező módosulásokra.

C50 anyagon végzett vizsgálataink $\mathrm{Ra}$, $\mathrm{Rz}$ értékeit a 4. ábra mutatja be. $\mathrm{Az} \mathrm{Rz}$ paraméternél a szerszámkopás hatására bekövetkező eltérések mértéke több mint háromszoros. A forgácsolási folyamat alatt a szabályos élalak eltünik és sajátos átmásolódási mechanizmus alakul ki [2].

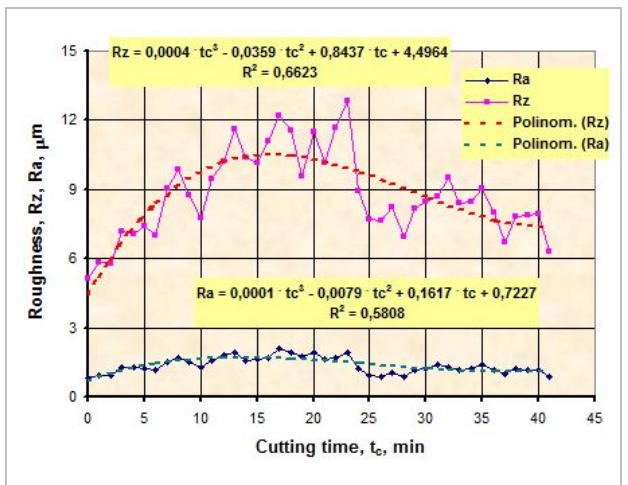

4. ábra. $A z$ Ra és Rz értékek alakulása esztergáláskor $\left(v_{c}=300 \mathrm{~m} / \mathrm{min}\right.$;)

A felületi mikrogeometria alakulását jól szemléltetik az 5. ábra érdességi profildiagramjai, amelyeken az előzőekben leírt, az élalak és az esztergált felület közötti kölcsönhatások jól érzékelhetőek.

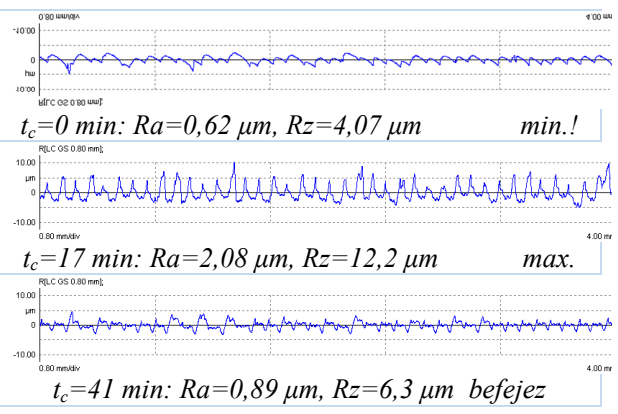

5. ábra. Az érdességi profildiagramok alakulása a forgácsolási idö alatt

\section{A mart felület kialakulása}

Itt az általános hatások hasonlóak, mint esztergálásnál, de mivel több fog dolgozik egy körülfordulási ciklus alatt, a szerszám geometriai hibái sokkal nagyobb szerepet kapnak. Ezt a tényt az elméleti levezetések, illetve a szakirodalomban közölt vizsgálati adatok részben már jelzik [4]. Legtöbb cikkben viszont a forgácsoló sebesség $\mathrm{v}_{\mathrm{c}}$, az előtolás $\mathrm{f}_{\mathrm{z}}$, illetve a megmunkált anyag hatását elemzik a kapott felületi érdességre, és nem veszik figyelembe a szerszám fogainak, illetve a szerszámbefogó orsó pontosságának hatását.

Egyetemünkön végzett kutatások igazolják, hogy a felület messze nem egyenletesen alakul a marás során [5]. A mart felület érdességét többségében a legnagyobb ütésủ fog alakítja ki (6. ábra - Szerszám: Ø8mm ujjmaró, Anyag x20Cr13 Technológiai paraméterek: $\mathrm{v}_{\mathrm{c}}=100 \mathrm{~m} / \mathrm{min}, \mathrm{a}_{\mathrm{e}}$ : $2,5 \mathrm{~mm} \mathrm{a}_{\mathrm{p}}: 10 \mathrm{~mm} \mathrm{f}_{\mathrm{z}}=0,1 \mathrm{~mm}$ ).
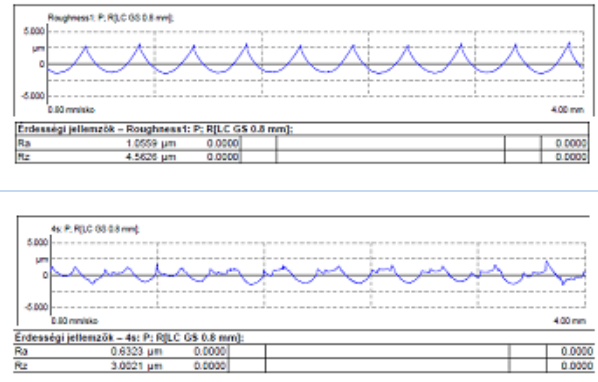

6. ábra. Valós érdességmérés eredményei

Ez azt jelenti, hogy a fogankénti előtolás $\mathrm{f}_{\mathrm{z}}$ hatása elvész, s szerepét a fordulatonkénti előtolás $\mathrm{f}$ veszi át. Ideális esetben, ha sem a szerszámbefogásnak, sem a szerszám fogainak nincs ütése, akkor adódik az $\mathrm{f}_{\mathrm{z}}$ és a maróátmérö geometriai hatására a minimális elméleti Rz felületi érdesség, a maximális értéket pedig a fordulatonkénti előtolás $\left(\mathrm{f}=\mathrm{z} \cdot \mathrm{f}_{\mathrm{z}}\right)$ hatásaként kapjuk. 


$$
R_{z}=\frac{f_{z}^{2}}{8 * R_{s z}}, \quad \text { és } \quad R_{z}=\frac{f^{2}}{8 * R_{s z}},
$$

ahol $\mathrm{R}_{\mathrm{sz}}$ - a marószerszám sugara.

A várható valós $R z$ egyenetlenségmagasság érdességi értékek tehát a fenti képletek által meghatározott (min...max) tartományban helyezkednek el, függően attól, hogy a forgácsoláskor adódó szerszámütések milyen mértéküek.

$\mathrm{R}_{\mathrm{sz}}=4 \mathrm{~mm}$ sugarú, $\mathrm{z}=4$ fogú ujjmaróval $\mathrm{f}_{\mathrm{z}}=0,1 \mathrm{~mm}$ fogankénti előtolással forgácsolva ez $k b . R z=0,3 \mu \mathrm{m}$ és $R z=4 \mu \mathrm{m}$ értékek között alakul (lásd 7. ábrát). A minimálishoz közeli Rz érték kialakulását még elvétve sem tapasztaltuk!

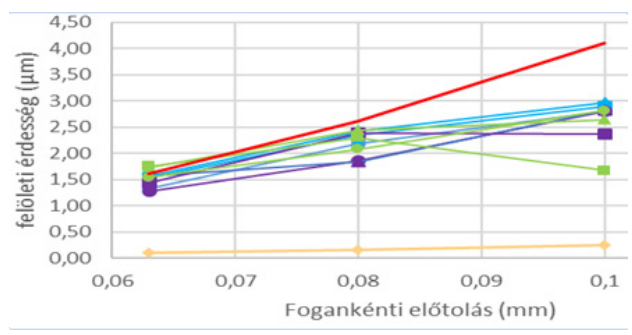

7. ábra. A valós marási kisérletek eredményei

Az előbb említett problémát vizualizálja a 8. ábra, amely az elméleti érdesség, és az egyre nagyobb ütéssel rendelkező szerszám által előállított elméleti felületeket mutatja.

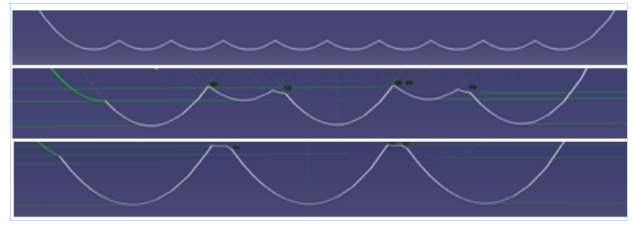

8. ábra. Az elméleti érdességi profilok alakulása (Rzmin...Rzmax)

A szerszám és a befogórendszer pontatlanságait ismerve, illetve bemérve, a várható $\mathrm{Rz}$ felületi érdesség a fenti szimulációval jól modellezhető. A fentiekből viszont egyértelmüen következik, hogy marásnál a felületi érdesség és a technológiai paraméterek, illetve a megmunkálandó anyag kap- csolata, az igen pontos gép és szerszám feltételek mellett is csak fenntartásokkal vizsgálható és elemezhető.

\section{4. Összegzés, következtetések}

Gyártásnál és minőségellenőrzésnél mindig figyelemmel kell lenni arra, hogy a felületképzés a forgácsoló szerszám elhasználódási folyamata közben valósul meg.

A szerszám kopása és annak időbeli változása visszahat a megmunkált felületre. Ez esztergálásnál a megmunkált felület érdességét alakító csúcshátlap kopási jellegzetességeire vezethető vissza: megváltozik a mikrogeometriai profil jellege, az általánosan ismert $\mathrm{Ra}$ és $\mathrm{Rz}$ érdességi paraméterek értékei pedig akár 200-300\%-os eltérést is mutathatnak a szerszám éltartama alatt.

Több élű szerszámoknál, így főként marásnál a szerszámok eltérő gyártási pontossága, éleinek ütése meghatározóan befolyásolja a forgácsoláskor kialakuló felületi érdességet. Ezért más technológiai paraméter érdességre való hatásának vizsgálatakor ezt feltétlenül figyelembe kell venni.

\section{Szakirodalmi hivatkozások}

[1] G. N. Tóth, Á. Drégelyi-Kiss and B. PalástiKovács: Analysis of microgeometrical parameters of cutting surfaces, Pollack Periodica, Vol. 8, No. 2, pp. 55-66 (2013)

[2] B. Palásti-Kovács, S. Sipos, Sz. Bíró: The Mysteries of the Surface First Part: The Characteristic Features of the Microgeometry of the Machined Surface, Acta Polytechnica Hungarica, Vol.11 No.5 2014. p.5-25

[3] J-E. Stahl, F. Schultheiss, S. Hagglund: Analytical and Experimental Determination of the Ra Surface Roughness during Turning, Procedia Engineering, 19 (2011) p. 349-356.

[4] M. Krüger, B. Denkena: Model-based identification of tool runout in end milling and estimation of surface roughness from measured cutting forces, Int J Adv Manuf Technol (2013) 65:1067-1080

[5] Ráczi V.: Az élpreparáció hatása nehezen forgácsolható anyagok marásakor, 2015.11.18. ÓE-BGK, TDK-dolgozat. 